\title{
Epic Fantasy and Global Terrorism
}

\section{Ken Gelder}

'If fantasy is the means by which we in some sense place ourselves "out of this world" at the "end of the world", it is also a means for securing our adaption to it' (Eric. L. Santner, On the Psychotheology of Everyday Life) ${ }^{1}$

There are many cues for an article like this, which looks at J.R.R. Tolkien's The Lord of the Rings - and in particular, the recent films of the trilogy, directed by Peter Jackson - alongside recent commentaries on, and anxieties about, the rise of global terrorism and the 'war on terrorism'. There have already been links drawn between these events and literary texts, of course: for example, Jason Epstein has compared the United States, in its pursuit of terrorists, to Melville's Ahab. ${ }^{2}$ But a more relevant cue comes from an article in the New Left Review by Mike Davis, which situates the aeroplane bombings of the World Trade Centre buildings in New York on September $11^{\text {th }} 2001$ in the context of fantastic images of the fire-storming of Lower Manhattan in a work by H.G. Wells, War in the Air, published eighty-four years earlier in 1907. Under zeppelin attack by Imperial Germany, 'ragtime New York', as Davis describes

it, 'becomes the first modern city destroyed from the air'. ${ }^{3}$ Davis is one of a number of commentators on S11 who reads the reality of the event through the logic of fantasy, as if it was a moment of terror, or terrorism, that made it impossible to distinguish between the two: 'the attacks on New York and Washington DC were organised as epic horror cinema with meticulous attention to mise en scene. Indeed, the hijacked planes were aimed to impact precisely at the vulnerable border between fantasy and reality' (p.37). That phrase - 'the vulnerable border between fantasy and reality' - also resonates with anxieties about terrorist activity itself, planned and executed (in this case) from within the borders of the US, and so speaking to America's own sense of border vulnerability: of the possibility that the outside is already or always inside. This theme has preoccupied Davis through his work on Los Angeles in City of Quartz, which shows the city constructing itself around Manichean differences, Us (white, rich Americans) and Them (immigrants, Mexican-Americans, blacks, the urban poor). One reviewer notes the way in which Davis constructs Los Angeles' 'ruling classes' as 'forces of evil' in the city as they fortify their strongholds precisely to prevent 'border vulnerability'. 
Davis's article on S11 ends with a similarly extravagant account of the ruling class intensifying systems of surveillance directed against others: 'At a Halloween press conference, Colin Powell, sounding like he had just finished reading Neuromancer, gloated over plans for a vast centralized data warehouse that would store "every derogatory piece of information" on visitors and would-be immigrants' (p.50). Here, the US administration meets William Gibson and cyberpunk in the context of Evil manifest: the 'forces of evil' come out on All Soul's Eve.

It can indeed be difficult to extricate counter-terrorism policy from the realms of fantasy and fantasy discourse, the more so since terrorism (like Islamism, to which it is now so often aligned) became the US's demonised other. Are US terrorist targets real or fantastic? Mike Davis has noted that Los Angeles is also a target for destruction, or at least, for the fantasy projection of destruction: 'No other city seems to excite such dark rapture', he comments in his book, Ecology of Fear, at the beginning of a long chapter on the literary destruction of Los Angeles. ${ }^{5}$ It is, he says, 'the disaster capital of the universe' - obliterated in fiction and film at least 138 times since 1909 (p.276 ), an expression of fantasy wish-fulfilment: 'The obliteration of Los Angeles is often depicted as, or at least secretly experienced as, a victory for civilisation'. ${ }^{6}$ A sense that Davis relished the telling of the sequential story of Los Angeles' destruction - and self-destruction - led to accusations that he was paranoid or 'pathological', obsessed with the apocalypse, a fantasy writer himself, much in the tradition of H.G. Wells. 'I've profited greatly from peddling apocalyptic visions to people', he admits in an interview with Mark Dery. ${ }^{7}$ Indeed, in a curious loop, Mike Davis came to influence William Gibson's later novel, Virtual Light, where City of Quartz is cited as an important source for Gibson's fictional representation of LA. These days, of course, film and fiction may be working hard to prevent Los Angeles from being obliterated, as we see with the counter-terrorism unit in the second series of the television thriller, 24. The fantasy here sees rich, white Los Angeles Americans (the blonde sister, Marie) conspiring with Muslim fundamentalists, each equally responsible for terrorism as if the differences between Us and Them, inside and outside, Good and Evil, are no longer clear. For one of 24's writers, Virgil Williams, this is a matter not of fantasy at all, but of reality: 'Just because the flavour of the month right now is fundamentalist Islam, that may sort of amplify those characters we have on 24 who are fundamentalist Muslims and not good guys. That's real. Just like there are blond-haired, blue-eyed domestic Timothy McVeighs killing our own people'.

Another cue that helps to develop the connection terrorism and fantasy - and especially, Tolkien's The Lord of the Rings - is this one: a visual image that has been circulating around the internet, titled 'Frodo has failed', showing George W. Bush wearing the Ring of Sauron. 


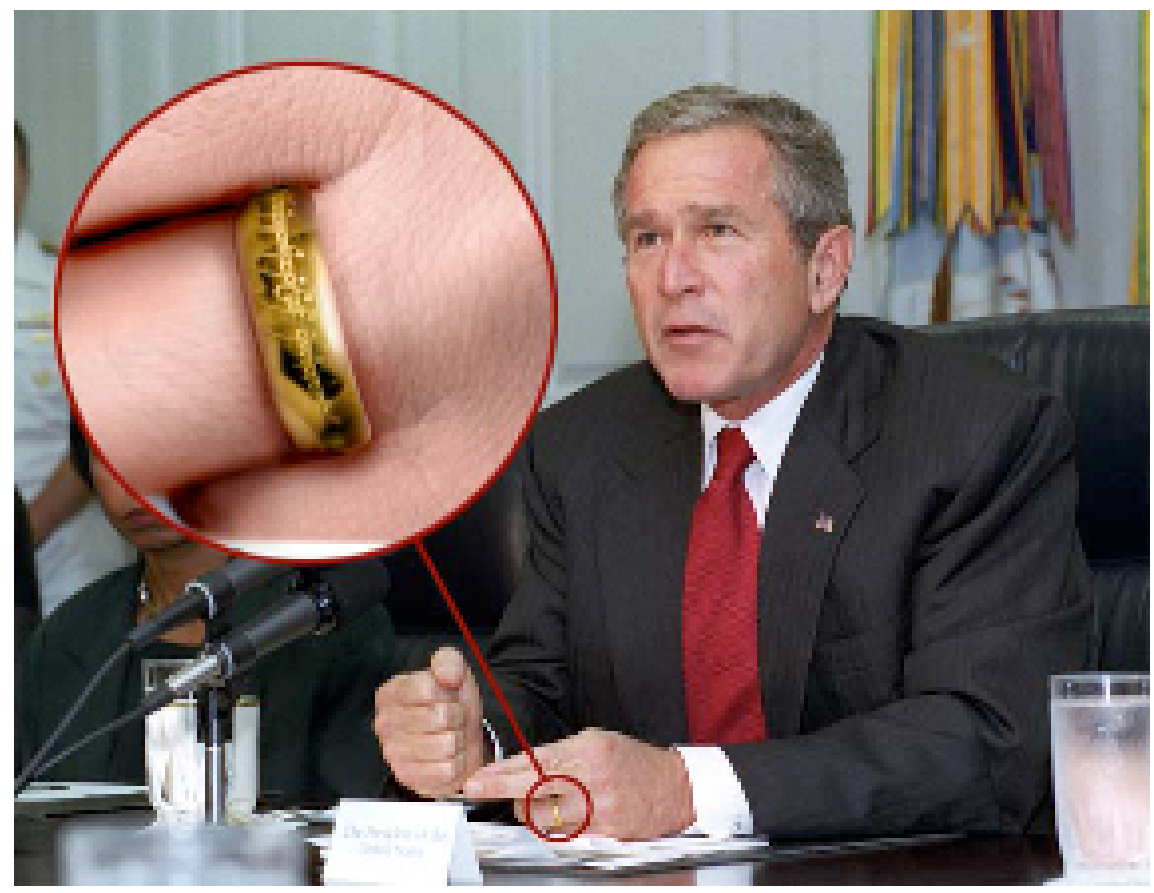

Source: http://www.myirony.com/archives/000206.html

This jpg is taken from just one of many sites showcasing the image: www.myirony.com, posted February $2^{\text {nd }}, 2003$ and it is titled: 'Frodo has failed: Sauron prepares to invade Iraq'. Myirony.com is an open website and people offer their own commentaries on what it posts. Here is one of them, posted underneath the image of Bush wearing the Ring of Sauron:

Sauron was trying to take away the freedom of the peoples of Middle Earth. Is Bush doing the same thing? Is taking away the freedom of a corrupt and dangerous government truly evil? OK - so I just set myself up for the comment that some people think the US is corrupt and dangerous. But, are we as corrupt and dangerous as Iraq? Is the current administration making up the stories of Iraqi horrors? It seems to me that Saddam Husein is a very bad man and his regime puts the US at high risk. One thing is for sure. The current technology of weapons means that wars can't be fought on old terms. The idea of preventing Saddam from hurting us before it happens might sound a bit like 'Minority Report' ... but, what if none of the war-talk had ever happened? Would we have been the victims of an attack from Saddam or terrorists he's funded? If so, wouldn't we all wish we'd gone to war?

This posting captures an ambivalence found in much of the commentary on terrorism and the 'war on terrorism' today: an ambivalence that wonders whether the 'evil empire' of the U.S. is more, or less, evil than terrorism itself - or than the three so-called 'rogue states' that George W. Bush identified as the 'axis of evil', states that may well have lent (or could be about to lend) terrorism their support. The tentative future tense here is noted in the posting, connected to another fantasy text, Minority Report - which is followed in turn by a sequence of fantasy projections that work again as wish-fulfilments ('wouldn't we all wish we'd gone to war?') but 
only in some indeterminate past-future realm ('would we have been the victims...'). This is terrorism as phantasm: a terrorism that is yet to make itself manifest: a terrorism in which the principal villain, like Sauron himself in The Lord of the Rings or like Osama bin Laden, is both manifest and simply not there.

As it is currently conceived, what is now called global terrorism has both an immediately felt and an ethereal 'body': a violently-registered presence, and a disconcerting absence that seems almost against the odds to continue to keep itself that way. For Binoy Kampmark, in an article titled 'The Spectre of bin Laden in the Age of Terrorism', written for the online journal CTheory, bin Laden is a kind of hyperreality, living as a perpetual 'afterlife', his body and voice needing ceaselessly to be verified or authenticated. ${ }^{9}$ Indeed, Kampmark argues that bin Laden needs to be absent for the 'war against terrorism' to properly function, especially through its globalised agendas (which means that, for the US, there is no place it cannot go in pursuit of this absence). Roland Jacquard's book, In the Name of Osama bin Laden: Global Terrorism and the bin Laden Brotherhood, makes a similar point about bin Laden's terrorist organisation itself: that 'al_Qaeda, bin Laden's creation, no longer needs either his physical existence or his funds; a live or dead, he has become a talisman for a diffuse, self-sufficient terrorist network with every intention of fulfilling its mission to "lead the world into the apocalypse". ${ }^{10}$ These various tropes, yoking terrorism to an absent source, to phantasm, but also to networks of alliance and to a global apocalypse, should begin both to identify and clarify the connection between terrorism and fantasy - specifically, the modern genre of epic fantasy consolidated in Tolkien's The Lord of the Rings.

Tolkien famously disavowed allegorical readings of The Lord of the Rings ('It is neither allegorical or topical'), partly to distinguish himself from the fantasies written by his friend and colleague, C.S. Lewis. ${ }^{11}$ But allegorical readings of his work are nevertheless commonplace, especially those that place the fantasy works in the context of Tolkien's own experiences during the First World War where he lost a number of close friends and was himself stricken with 'trench fever'. The three parts of The Lord of the Rings were written during the 1930s and throughout the duration of the Second World War, with the first part - The Fellowship of the Ring, published in July 1954. Part two, The Two Towers, was published in November 1954, and Part three, The Return of the King, was published in April 1955. Peter Jackson's cinematic version of The Lord of the Rings has become the most expensive set of films ever made; the film of the first part appeared just a few weeks after S11, and the annual release of the other parts mean that they are necessarily caught up alongside the 'war on terrorism', the invasion of Iraq and the search for 'weapons of mass destruction' (another phantasm, thus far), and the search for Osama bin Laden and global terrorist cells and networks. It is certainly possible to situate the The Lord of the Rings cinematic project - which also saw Tolkien's novels republished by HarperCollins and return to the top of US bestseller lists alongside non-fictional accounts of Osama bin Laden, terrorism and Islam - in this prevailing context. Indeed, several commentaries have already done this, to greater or lesser degrees. 
The Center for Libertarian Studies is a non-profit organisation based in Burlingame, California, with a website that links to Antiwar.com for coverage of US foreign policy. It also links to LewRockwell.com, a site owned by the CLS's vice-president who identifies himself as 'an opponent of the central state, its wars and its socialism' : an opponent, that is, of Colin Powell's Halloween 'gloating' over increased internal US surveillance systems. Carlo Stagnaro, an Italian who is co-editor on the Libertarian magazine Enclave and who has written a book on Waco, has posted an article on this site, titled 'Tolkien's Lesson for September 11'. 'The conservative and liberal élites', he writes, 'have been portraying Bush's war on terrorism as a sort of crusade of good against evil. They have even tried to enlist John Ronald Reuel Tolkien...author of the "Book of the Century", The Lord of the Rings, for this endeavour. In their view, the coalition led by the United States is like the "league of the free" who fight against Sauron of Mordor - that is, bin Laden of Afghanistan'. ${ }^{12}$ This is an informed article that counters the conservative appropriation of Tolkien's work, placing Tolkien in a tradition of civil dissent: 'J.R.R. Tolkien', he writes, 'would hardly have taken a position in favour of the war on terrorism'. The aim of Tolkien's work is the destruction of the Ring itself, the source of unlimited and always-corrupting power - a point which leads Stagnaro not to read the fantasy of The Lord of the Rings as an allegory for reality, but the inverse, that is, to read reality as an allegory for fantasy:

today's war on terrorism seems a war to own the Ring, rather than a war to destroy it. Neither Bush's nor bin Laden's supporters fight for liberty; they all fight to strengthen their own power. One can hardly choose to join one or the other - and should ask whether there is still a place for common, peaceful people in the lands of opposing war lords. Indeed, the only rational position is that of Treebeard [an Ent in The Lord of the Rings]: 'I am not altogether on anybody's side, because nobody is altogether on my side, if you understand me....And there are some things, of course, whose side I'm altogether not on; I am against them altogether'.

Here, The Lord of the Rings provides the means of articulating one's position on global terrorism: this epic fantasy text from the 1950s now accommodates a contemporary war scenario. It 'picks up' a terroristic allegory - as Chris Mooney notes in an article first published in The Washington Post on $29^{\text {th }}$ December 2002 (around the time of the release of the film of The Two Towers), titled, precisely, 'Tolkien picks up a few more bits of cultural baggage'. Mooney focuses on the orcs in the epic fantasy as dissenters, complaining about the Ringwraiths and wanting only to be able to slip away and loot in a place where there are no 'big bosses'. 'One can easily imagine', Mooney writes, 'a similar conversation among lowerlevel al Qaeda henchmen or Iraqi troops'. ${ }^{13}$ Mooney then goes on to register the ambivalence of evil, both in the novel and in the context of global terrorism: 'The analogy between bin Laden and Sauron is not an empty one', he writes, but 'for the bearer of the Ring of Power, he would need to look no further than George W. Bush'. 
The final commentary to note here comes from the Hong Kong-based Asia Times Online: a front-page piece titled 'The "Ring" and the remnants of the West', by a correspondent identified only as 'Spengler' - named after Oswald Spengler, author of The Decline of the West (1918 - 1922). This commentary takes the release of the films of The Lord of the Rings as the 'most important cultural event of the past decade', since in these texts 'No better guide exists to the mood and morals of the United States'. ${ }^{14}$ It charts Tolkien's relation to Wagner and the Ring of the Nibelungs cycle, seeing them both - even though Tolkien thoroughly 'recast' the earlier text - as elegies that track the departure of the immortals: in Tolkien's case, the Elves, who finally renounce the world and depart. The difference between Wagner and Tolkien's works is that whereas the former was neo-pagan and heroic, the latter is Christian (Tolkien was a devout Catholic) and anti-heroic, centred on the role of the hobbit Frodo as Ring-bearer, who wishes that the Ring 'had never come to me'. Spengler reads the end of The Lord of the Rings as a return to ordinary life, therefore casting the work not as epic fantasy at all, but as anti-epic - and reading the US accordingly not as empire, but as anti-empire: 'Boorish and gruff as the new American empire might seem, it is an anti-empire populated by reluctant heroes who want nothing more than to till their fields and mind their homes, much like Tolkien's hobbits. Under pressure, though, it will respond with a fierceness and cohesion that will surprise its adversaries'.

In this article from the East about the West, Americans are like hobbits, content to remain in the West, insular, isolated from the pressures of globalisation, in this case, global terrorism. This is a commonplace view of the US, an empire-building nation that can also seem ignorant of the world beyond its own vulnerable borders, a view deployed by (for example) Naomi Klein in a short article first published in The Nation in October 2001: 'In the weeks since September 11, we have been reminded many times that Americans aren't particularly informed about the world outside their borders'. ${ }^{15}$ Of course, if the hobbits have any equivalent nationality in the real world at all, they're probably English: certainly, Tolkien claimed them as such, locating the Hobbits' Shire just outside of Oxford where he worked as a Professor of Anglo-Saxon. His biographer Michael White notes that Tolkien liked to identify himself as a hobbit, sealed off from the outside world in 'his ivory tower in Oxford'. ${ }^{16}$ Tolkien's Oxford his hobbits' Shire - is echoed in Michael Taussig's essay on terror in The Nervous System, when he describes an American university where a discussion of state terrorism is being held: a 'middle class, largely white, fortress', as he puts it, 'with fear-ridden blocks of lofty spires': 'a perfect copy of an Oxford college'. ${ }^{17}$ Fantasy and reality are entangled in Oxford and then simulated in America in this trajectory. But through the production and release of Peter Jackson's recent films of The Lord of the Rings, a further and even greater simulation takes place: the identification of Middle Earth itself with New Zealand.

The three films in The Lord of the Rings series were filmed on location in New Zealand, using scenery in both the North and South Islands: when The Fellowship of the Rings won an Oscar 
for cinematography, tourist officials jokingly claimed their nation as the 'Best Supporting Country'. New Zealand has been quick to capitalise on the tourism value of its association with Tolkien's fantasy world. The capital, Wellington, was officially renamed 'Middle Earth' when The Fellowship of the Rings was released in December 2001: and, as Tolkien-based tourism flourished across the islands, the minister for tourism became known as the 'Minister Responsible for Lord of the Rings'. Air New Zealand has painted two of its planes with images from the films and has adopted the slogan, 'The Airline to Middle Earth'. The New Zealand Tourism website has mapped out New Zealand according to the set locations of the films, imprinting the Shire, Mordor and many other fantasy locations onto the landscape of New Zealand: see 'New Zealand, Home of Middle Earth' (http://www.newzealand.com/homeofmiddleearth/). In the wake of S11 and the 'war against terrorism', this kind of fantasy identification has a particular resonance. New Zealand Tourism speaks of New Zealand as a 'safe destination' in an otherwise unsafe world: much like the Hobbit's Shire just prior to the events of The Lord of the Rings. New Zealand has demilitarised itself and no longer contributes to the Australian-US alliance. It also refused to join the 'coalition of the willing' in the war on Iraq, distinguishing itself carefully from Australia in this matter. At the same time, The Lord of the Rings films have given New Zealand global recognition: through scenery that is simultaneously natural and otherworldly; and through the development of sophisticated computer-generated effects, locally and cheaply produced, that have made New Zealand the preferred destination of other cinematic fantasy productions. New Zealand in this account becomes a place that (according to Peter Jackson) 'fits' Middle Earth perfectly even though it doesn't belong there: a safe fantasy space in a globalised world, a remote and tiny nation identified both locally and globally as terrorist-free (which is precisely the fantasy at stake in this identification).

Jacqueline Rose has been the only recent commentator to draw together fantasy and nation, although she takes fantasy as a psychic condition, not a literary genre. In States of Fantasy, Rose nevertheless begins her commentary precisely by following the formula of modern epic fantasy. That is, she goes on a quest: 'This book begins in 1980', she writes, 'during a visit to Israel', taking its own cue from a journey 'to a country where you do not belong'. ${ }^{18}$ Exile becomes the means of experiencing a fantasy state, belonging yet no longer belonging - like Freud when he leaves Vienna, and like Frodo when he leaves the Shire. The state itself exerts a magical, fantasmatic power over its subjects, as Max Weber had noted (cited p. 8); but fantasy also travels beyond the state (like the exiled Jew or hobbit) and so both undoes it and provides a means of articulating its deepest yearnings. Modern epic fantasy also plays out this role, protecting the state's identity and yet troubling the state as it continually moves beyond its borders - or renders its borders vulnerable or porous, as the Shire becomes in The Lord of the Rings. It is still common to regard fantasy works as, to quote the title of a recent study of the genre by Richard Mathews, a vehicle for 'the liberation of the imagination'. ${ }^{19}$ But modern epic fantasy continually worries about the place it has left (usually, traumatically), about its borders and its vulnerability, about whether that original or originating place can still be, like New 
Zealand, a 'safe destination'. Fantasy knows that 'liberation' must also (like the war on Iraq) entail occupation, border protection, regulation, surveillance, constraint - as characters and places lose their identities, only to return to them in desperation (and nostalgically) over and over again.

Epic fantasy grew out of the experiences of world wars, to become literally the grandest and greatest of the literary genres: nostalgic for 'safe destinations', but charting the vulnerability of borders and identities with an almost masochistic intensity. The genre can therefore often refuse to resolve itself: a recent epic fantasy series by Robert Jordan, for example, is now in its tenth volume (each one around 600 pages), with no signs even at this stage of reaching (to use a word often associated with traumatic memory) 'closure'. Tolkien's sagas also grew, escalating into a series of volumes published posthumously by his son, Christopher, as if the battles and struggles can never stop or be stopped. Indeed, the genre charts what Dilip Hiro, in a book on the global response to Islamist terrorism, has called a 'war without end' ${ }^{20}$ - or what Michael Taussig in his chapter on terrorism refers to as a permanent state of emergency, now a familiar phrase later echoed by George W. Bush himself when he declared a 'state of perpetual emergency' after S11: advocating, as Fredric Jameson has also noted, 'a new sort of war without... a foreseeable end'. ${ }^{21}$ Characters in modern epic fantasy are mobilised on a quest that may similarly be endless, sent to realms beyond their borders, as the hobbits are in The Lord of the Rings or as Lyra is in Philip Pullman's recent series, His Dark Materials, which actually begins in the ivory towers of Oxford; exile is necessary in epic fantasy. Indeed, they travel incessantly, almost obsessively, into other lands and other people's territories. It is evil that drives them outwards: it comes into their home (that is, it is proximate) and yet it remains utterly remote, distant, absent, unable to be seen even as its effects are continually registered: much like the perpetual absence of Osama bin Laden. In The Lord of the Rings, Sauron is an eye that sees the hobbits only when they become invisible; paradoxically, when they can see themselves they remain out of Sauron's sight. Jane Chance, in her book on Tolkien, thus reads the fantasy works in the context of Michel Foucault's account of the Benthamite panopticon with its universal 'gaze', which is as good a reading as any. ${ }^{22}$ A similar reading might turn back to Michael Taussig, who describes the atmosphere of terror as one 'whipping back and forth between clarity and opacity', generated centrally through some organisational force and yet which is radically de-centred, everywhere: 'an eye watching', he says, 'an eye knowing' (p.21).

The best academic study of Tolkien's work is Tom Shippey's book, J.R.R. Tolkien: Author of the Century. Shippey's discussion of evil in The Lord of the Rings emphasises both its power and its intangibility, signified through the Ringwraiths: shadowy figures who were once men but who were utterly changed through their 'addiction' to the Ring - and who seem able to go anywhere in Middle Earth, creating 'panic'. ${ }^{23}$ These are certainly terroristic creatures: 'The spectacle of a person "eaten up inside" by devotion to some abstraction has been so familiar throughout the twentieth century as to make the idea of the wraith, and the wraithing-process, 
horribly recognisable, in a non-fantastic way' (p.125). Links between fascism and terrorism drawing the mid-twentieth century into the end of the millennium - have been made by commentators such as Christopher Hitchens; but it seems to me that Tolkien's shadowy, paniccausing Ringwaiths are more terrorist than fascistic both in their devotion to abstractions and their sheer otherness. Shippey has a slightly different argument to run, however. For Shippey, the Ringwraiths and the Ring itself form the two sides of evil in the fantasy work. The first is 'Boethian', generated internally: absent as a thing-in-itself, and caused self-alienation and corruption. The second is Manichean, generated externally: an outside force, remote but powerful, and never inactive. The Boethian conception of evil is cast by Shippey as a literary trope, deployed especially by Tolkien's modernist counterparts: 'the cosseted upper-class writers of the 'modernist' movement', as Shippey calls them (p.142) whose interests lie in what Foucault called the care of the self: in ethics. Epic fantasy, however, is able to deploy the Manichean conception of evil as well, which for Shippey thus makes fantasy (unlike modernism) more directly relevant 'to the real world of war and politics': communal, not individualised, universal and not contingent, militant rather than dialogic - or dialogic only through its militancy. A better philosophical model might lie in the work of Alain Badiou, who thinks ethics out of the realm of self-interest and back into the realm of the universal and the community, with its 'militant conception of truths', its 'combative' approach to situations and its commitment to 'what is going on'. ${ }^{24}$ Badiou has also mobilised the concept of Evil as a universal category.

This philosopher has argued with Levinas, whose own ethics is underwritten by the requirement that one come face to face with the Other, the 'Altogether-Other', or God. For Badiou, there is no God; his own project is irreligious, and that Levinasian respect for differences is dismissed as a project of Sameness. Sameness is embraced here, rather than refuted: truth is, he writes, indifferent to differences, 'the same for all' (p. 27). Badiou's conception of Evil is important to note here since it is terroristic, and close to the logic of epic fantasy - although few philosophical readers of his work may agree. Evil, he writes, has three names: terror, betrayal and disaster (p.71). An 'ethic of truths' attempts to ward these off even as it is entangled in them., needing them dialectically. Badiou's concept of Evil is a delirious one, literary in its nature (a 'simulacrum of truth') and terroristic in essence: 'a terror directed at everyone' (p.77). Terroristic evil is itself a simulacrum, a betrayal of the truth - in response to which (in order to 'ward off Evil') one can only 'Keep going!'. Indeed, Badiou advises much in the way of epic fantasy - the following resources: 'discernment (do not fall for simulacra)...courage (do not give up), and...moderation...(do not get carried away to the extremes of Totality)' (p.91). This account may be religious in spite of itself. But certainly, it is difficult not to think of Frodo and Sam here as they make their way to Mount Doom, trying almost beyond endurance not to fall for the simulacra of the Ring itself - trying not to get carried away by the 'extremes of Totality' offered to them by Sauron, an image of Evil so deep and resonant as to appear unmotivated: simply and always there, somewhere. 
Terror in this account is both proximate and remote, here and always at the same time elsewhere. It has something sublime about it, as Taussig has noted and has Ann Radcliffe had noted in 1826 through her classic distinction between terror and horror which, she noted, 'are so far the opposite, that the first expands the soul, and awakens the faculties to a high degree of life; the other contracts, freezes, and nearly annihilates them'. ${ }^{25}$ Terror is a ceaseless, immanent threat here, like Taussig's permanent state of emergency, in relation to which one can indeed only 'Keep going!' - while horror realises that threat, bringing atrocities close to home, provoking a sickening disgust, a state of despair. To borrow terms used by Jean Baudrillard, terror is fatal while horror is banal: the banal conclusion or realisation of terrorism. It is the task of epic fantasy - fantasy on the grandest scale - to mediate between the two, to hold them in some kind of balance. A perfect example lies in the work of the architect, Daniel Libeskind, who won the competition to build a set of new towers in the place of the World Trade Centre towers. Those WTC towers, designed by Japanese-American architect Minoru Yamasaki, were already, as Angus Kress Gillespie notes, 'a global symbol, instantly recognised to stand for America'. ${ }^{26}$ They had previously been a terrorist target and terrorism remained an immanent threat. Their bombing transformed the site into a place of horror, provoking disgust, despair, grief, anger: and Libeskind's new tower project seemed designed both to preserve these horrific features and at the same time to return the site to a condition of terror, of sublimity and immanence. Hal Foster captures this combination of horror and terror in the Libeskind design when he says it embodies 'both the traumatic and the triumphal': ${ }^{27}$ Libeskind, who also designed the Jewish Museum in Berlin, created for New York a spiral of high-rise towers culminating in a 1,776-foot spire, out-symbolising the WTC towers as a 'spire of liberty' through its echo of the Statue of Liberty - a work of epic fantasy, no less, a 'liberation of the imagination'. ${ }^{28}$ The angular towers around the spire are designed 'so that each year on September 11, between the hours of 8.46 am when the first plane hit, and 10.28 am, when the second tower collapsed, the sun will shine without shadow' ${ }^{29}$ Portentous names are given to various parts of the building: the memorial plaza is 'Park of Heroes', the museum is 'Edge of Hope', the spire itself is 'Life's Victorious Skyline'. 'Libeskind loves metaphor', Cathleen McGuigan has noted, 'a ruin at the bottom; life blooming at the top' (p. 62). Herbert Muschamp, the architecture critic of the New York Times, declared, 'If you are looking for the marvellous, here's where you will find it'. ${ }^{30}$

It was difficult not to notice the synchronicity between New York's destroyed twin towers and the second book of Tolkien's epic fantasy, The Two Towers - signposted as an already completed film-yet-to-come shortly after the S11 attacks. Tolkien's dark towers (and so many works of epic fantasy have dark towers) are evil and remote; New York's towers became proximate; both functioned as 'marvellous' symbols, installed at the centre of some sort of epic struggle. The fantastic aspect of the twin towers and of the S11 attacks themselves was not lost on some of the better-known cultural commentaries that followed. Slavoj Zizek's essay 'Welcome to the Desert of the Real' takes its title from Jean Baudrillard via The Matrix (1999), drawing on that film's evocation of fantasy as false comfort - with the rubble of S11 as the real 
and banal supplement to the fantasised abstraction of the towers themselves. Everything in this reading is infected by fantasy: the dream of the United States as a safe haven, for example; or the identification of Osama bin Laden as 'the real-life counterpart of Ernst Stavro Blofeld, the master-criminal in most of the James Bond films, who was involved in the acts of massdestruction'. ${ }^{31}$ The US, creating 'catastrophes' everywhere else, also ceaselessly imagined its own self-destruction, so that 'in a way', on S11, 'America got what it fantasised about' (p.387): just as Mike Davis had said of Los Angeles. Baudrillard himself, in 'L'Esprit du Terrorisme', takes this point a little further, reading fantasy as wish-fulfilment: 'We could even go so far as to say it is they who perpetrated the attack, but it was we who wished it'; 'The West', he adds, 'has...declared war upon itself'. ${ }^{32}$ Baudrillard puts into effect precisely the fantasy of The Lord of the Rings, that 'power itself is accomplice with its own destruction' . The nearer it is to 'perfection', the faster it propels itself towards self-destruction: Baudrillard has no time for epic fantasy (or catastrophic film), of course, advocating instead the kinds of imperfection one might be expected to find in literary novels. Even so, S11 seemed to show through its very spectacle that reality and fiction, as he writes, 'have become a tangled mess' (p.413), impossible to disentangle: the kind of condition Tolkien himself ascribed to children, the most 'natural' readers of epic fantasy. ${ }^{33}$

These commentaries return to the question posed by commentators on the 'war against terrorism' at the beginning of this paper, namely, where is the greater evil: here, or there? Inside or outside? In the West, or elsewhere? Epic fantasy's ambivalent conception of evil, as I have noted, locates it inside and outside simultaneously - although, since hobbits survive the corrupting power of the Ring, it may finally lean towards the latter. Evil performs at its most terroristic as a remote Other, like Sauron and his network of alliances. It has in fact been commonplace to talk these days of terrorist 'networks', dispersed groups which affiliate across and beyond state borders to conduct what has been called a 'netwar', where the 'protagonists...use networked forms of organisation, doctrine, strategy and technology attuned to the information age'. ${ }^{34}$ Networked alliances have been crucial to modern epic fantasy: think of Sauron and the orcs, trolls, warcs and various birds and so on in The Lord of the Rings, or the witches, the gypsies and the armoured bears in Philip Pullman's trilogy. The Lord of the Rings even deploys its own 'coalition of the willing' to deal with these networks, the 'fellowship' between men, elves and dwarves: it might be worth thinking of Bush, Tony Blair and Australia's John Howard as real-life counterparts to Aragorn, Legolas and Gimli. These leaders' counter-terrorist discourse has absolutely relied upon a Manichean conception of evil from which liberal democracy in the West is then earnestly distinguished. But there have been plenty of recent academic and journalistic commentaries operating in exactly the same way. Roger Scruton's The West and the Rest: Globalisation and the Terrorist Threat provides a spectacular recent example: an hysterical commentary which sees the West under threat from a network of 'death-intoxicated' Islamist 'brotherhoods' whose effect has been intensified and extensified, paradoxically perhaps, by western-driven globalisation. Here is a passage that might just as easily been written about modern epic fantasy (and which is the exact mirror 
image of the view of Americans given in Asian Times Online, as an 'anti-empire populated by reluctant heroes who want nothing more than to till their fields and mind their homes' until global 'pressure' activates them): 'In the days when East was East and West was West, it was possible for Muslims to devote their lives to pious observances and to ignore the evil that prevailed in the dar-al-harb [house of war]. But when that evil spreads around the globe...old antagonisms are awakened, and with them the old need for allies against the infidel'. ${ }^{35}$ The work of Bernard Lewis (What Went Wrong?) or Simon Reeve (The New Jackals) or any number of media commentators following in the wake of Samuel Huntington's 'clash of civilisation' prognosis, reproduce the apocalyptic scenarios of modern epic fantasy: Manichean divisions between the West and Islam, but also an increasingly intense form of entanglement brought about through globalisation (which therefore often also produces auto-critique). The opposing position is held by commentators such as Gilles Kepel and Edward Said. Kepel, in his book Jihad: The Trail of Political Islam, takes globalisation as the means by which the necessary isolationism of Islamism is being eroded, which leads him to read S11 as 'a desperate symbol of the isolation, fragmentation, and decline of the Islamist movement, not a sign of its irrepressible might' ${ }^{36} \mathrm{He}$ is, in short, against the rhetoric of modern epic fantasy: he is, in particular, anti-apocalyptic. Edward Said, like another recent commentator on the US and terrorism, Tariq Ali, advocates 'secularism' over 'fundamentalism', and is also antiapocalyptic: Islamists, he writes, 'have by and large lost the battle'. ${ }^{37}$ Said has been critical of Bernard Lewis, amongst others, for both homogenising and demonising Muslims 'as one terrifyingly collective person enraged at an outside world that has disturbed his almost primeval calm and unchallenged rule' (p.xxxii): he also stands against the counter-terroristic rhetoric of this now all-too-real modern epic fantasy, although he later adds that there is 'some measure of truth' to this apocalyptic model since 'appeals to Islam have fuelled resistance here and there...' (p.xxxv).

Modern epic fantasy is a form of literary fundamentalism that troubles secular ideals. But it also troubles the kind of political fundamentalism that relies on Manichean binaries of good and evil. For Said, Bernard Lewis and others satisfy a 'market' in the West of representations 'of a monolithic, enraged, threatening, and conspiratorially spreading Islam' which is 'much greater, more useful, and capable of generating more excitement, whether for purposes of entertainment or of mobilising passions against a new foreign devil' (p.xxviii). In this paper, I have noted that modern epic fantasy can indeed generate an 'excitement' that can certainly rely upon a 'monolithic' representation of evil, terroristic in its incarnation. But in a work like The Lord of the Rings, the question of where evil actually resides is never fully resolved: it remains, as I have noted, inside and outside, here and there, simultaneously. Readers have remarked on the despair of The Lord of the Rings, as a work that turns upon itself, 'quietly running down', as Jenny Turner notes: 'It's a struggle with despair', she writes, 'a panoramic portrait of the depressive state' (pp.23, 24). The Otherness of the novels lies not so much in an externalised evil at all, but in what passes as the occulted world changes: the Elves in particular, who 'diminish' after Sauron has been destroyed. The video release of The Fellowship of the Ring 
was accompanied by a disc produced by National Geographic, which uses Tolkien to chart a commentary both on the impact of the world wars on Britain, and on a romantic mode of anthropology, concerned with the loss of ancient oral traditions. The latter focuses on the Finnish epic song tradition of the Kalevala, linking it to Tolkien's work on the language of the Elves - and mourning its passing from the modern world. The elegiac mode of the National Geographic disc shows another 'clash of civilisations', important to Tolkien as an anti-modern who loathed everything about the industrial West even though he ceaselessly registered its ever-encroaching presence. Michael White writes that Tolkien hated 'technologists, modernisers, polluters and inveterate consumers' (p. 209). His vehement anti-modern position can situate him, these days, perilously close to the prevailing caricatures of Osama bin Laden. For Colin Wilson, in fact, The Lord of the Rings was nothing less than an 'attack', as he saw it, 'on the modern world' (cited in ibid., 209). Epic fantasy, soaked through with nostalgia for lost traditions and dying cultures which it then systemtically reinvents and reanimates, has been venting its spleen on the modern world for over half a century now. This is another reason why it is possible to see epic fantasy today not as escapist, but as terroristic. 
References

${ }^{1}$ Eric L. Santner, On the Psychotheology of Everyday Life: Reflections on Freud and Rosenzweig (London and Chicago: University of Chicago Press, 2001): p.40.

2 Jason Epstein, 'Leviathan', The New York Review of Books, $1^{\text {st }}$ May 2003: pp.13-14.

${ }^{3}$ Mike Davis, 'The Flames of New York', New Left Review, 12 (2001): pp.34-50.

${ }^{4}$ Paul Murphy, review of Mike Davis's Ecology of Fear, Workplace (2001) (http://www.workplace-gsc.com/books/murphy2.html)

${ }^{5}$ Mike Davis, Ecology of Fear: Los Angeles and the Imagination of Disaster (London: Picador, 1998): p.277.

${ }^{6}$ Cited in Duncan Campbell, '24 reasons to be afraid in Los Angeles', The Age, $22^{\text {nd }}$ February 2003: p.2.

${ }^{7}$ Mark Dery, 'Downsizing the Future: Beyond Blade Runner with Mike Davis', Escape Velocity (2001) (http://www.levity.com/markdery/ESCAPE/VELOCITY/author/davis/html)

${ }^{8}$ Cited in Campbell, op. cit., p.2.

${ }^{9}$ Binoy Kampmark, , 'The Spectre of bin Laden in the Age of Terrorism', CTheory, $11^{\text {th }}$ April 2002 (http://www.ctheory.net/text file?pick=355).

${ }^{10}$ Vanessa Baird, review of Roland Jacquard, In the Name of Osama bin Laden: Global Terrorism and the bin Laden Brotherhood, New Internationalist, July 2002: p.31.

${ }^{11}$ J.R.R. Tolkien, 'Foreword to the Second Edition', The Fellowship of the Ring (London: HarperCollins, 2003): p. xx.

${ }^{12}$ Carlo Stagnaro, 'Tolkien's Lesson for September 11', LewRockwell.com (2002) (http://www.lewrockwell.com/orig2/stagnaro3.html)

${ }^{13}$ Chris Mooney, 'Tolkien picks up a few more bits of cultural baggage', Tolkien Online: The One Ring (2003) (http://www.tolkienonline.com/docs/8639.html)

${ }^{14}$ Spengler, 'The "Ring" and the remnants of the West', Asia Times Online, $11^{\text {th }}$ January 2003 (http://www.atimes.com/atimes/Front Page/EA11Aa02.html)

${ }^{15}$ Klein, Naomi, 'Signs of the Times', in Phil Scraton, ed., Beyond September 11: An Anthology of Dissent (London: Pluto Press: 2002): p.146.

${ }^{16}$ Michael White, Tolkien: a Biography (London: Little, Brown and Company, 2001): p.159.

${ }^{17}$ Michael Taussig, The Nervous System (London and New York: Routledge, 1998): p.15.

${ }^{18}$ Jacqueline Rose, States of Fantasy (Oxford: Clarendon Press, 1996): pp.1, 2.

${ }^{19}$ See Richard Mathews, Fantasy: The Liberation of the Imagination (London and New York: Routledge, 2002).

${ }^{20}$ See Dilip Hiro, War Without End: The Rise of Islamist Terrorism and Global Response (London and New York: Routledge, 2002).

${ }^{21}$ Fredric Jameson, 'The Dialectics of Disaster', South Atlantic Quarterly, vol.101 (2002): p. 310.

${ }^{22}$ Jane Chance, Lord of the Rings: The Mythology of Power (Lexington, Kentucky: The University Press of Kentucky): p.21.

${ }^{23}$ Tom Shippey, J.R.R. Tolkien: Author of the Century (London: Harpercollins, 2001): p.125.

${ }^{24}$ Alain Badiou, Ethics: An Essay in the Understanding of Evil, trans. Peter Hallward (London and New York: Verso, 2001): pp. xxxi, 2, 75. 
${ }^{25}$ Cited in Fred Botting, 'Horror', The Handbook of Gothic Literature, ed. Marie MulveyRoberts (London: Macmillan, 1998): p.124.

${ }^{26}$ Angus Kress Gillespie, Twin Towers: The Life of New York City's World Trade Centre (Piscataway, NJ: Rutgers University Press, 2002): p.5.

${ }^{27}$ Hal Foster, 'In New York', London Review of Books, $20^{\text {th }}$ March 2003: p.17.

${ }^{28}$ Cathleen McGuigan, 'A Tale of Two Towers', Newsweek, $10^{\text {th }}$ February 2003: p.62.

${ }^{29}$ Caroline Overington, 'Glass spire of liberty chosen as twin towers memorial', Age, $28^{\text {th }}$ February, 2003: p.12.

${ }^{30}$ Cited in Deyan Sudjik,, 'Towering Ambition', Sunday Age, $16^{\text {th }}$ March 2003: p.16.

${ }^{31}$ Slavoj Zizek, 'Welcome to the Desert of the Real', South Atlantic Quarterly, vol.101 (2002): p.387.

${ }^{32}$ Jean Baudrillard, 'L'Esprit du Terrorisme', South Atlantic Quarterly, vol.101 (2002): pp.404, 405.

${ }^{33}$ Jenny Turner, 'Reasons for Liking Tolkien', London Review of Books, $15^{\text {th }}$ November, 2001: p.17.

${ }^{34}$ John O. Voll, 'Bin Laden and the new age of global terrorism', Middle East Policy, vol.8 (2001): p.4.

${ }^{35}$ Roger Scruton, The West and the Rest: Globalisation and the Terrorist Threat (London: ISI Books, 2002): p.123.

${ }^{36}$ Gilles Kepel, Jihad: The Trial of Political Islam, trans. Anthony F. Roberts (London and New York: I.B. Tauris 2002): p.375.

${ }^{37}$ Edward Said, Covering Islam (New York: Vintage, 1997): p.xxvii. 


\section{University Library}

\section{- M M I N E R VA A gateway to Melbourne's research publications}

Minerva Access is the Institutional Repository of The University of Melbourne

Author/s:

GELDER, KEN

Title:

Epic fantasy and global terrorism

Date:

2006

Citation:

Gelder, K. (2006). Epic fantasy and global terrorism. In E. Mathijs \& M. Pomerance (Eds.), From hobbits to Hollywood: essays on Peter Jackson's Lord of the Rings (pp. 101-118). Rodopi.

Publication Status:

Published

Persistent Link:

http://hdl.handle.net/11343/35053 